\title{
Peculiar features of business incubators functioning: Ukrainian and world experience
}

\author{
Burhan Imanberdiev ${ }^{1}$, Alla Cherep ${ }^{2}$, \\ Oleksandr Cherep ${ }^{2}$, Tetiana Mostenska ${ }^{3}$
}

\author{
1 - Institut Sorbonne Kazakhstan of Abai Kazakh National Pedagogical University, \\ Astana, Republic of Kazakhstan \\ 2 - Zaporizhzhia National University, Zaporizhzhia, Ukraine \\ 3 - National University of Life and Environmental Sciences of Ukraine, Kyiv, Ukraine
}

\section{Keywords: \\ Business \\ Incubator \\ Entrepreneurship \\ Innovation \\ Agri-food sector}

\section{Article history:}

Received

12.03.2018

Received in

revised form

15.04.2018

Accepted

29.06.2018

Corresponding

author:

Alla Cherep

E-mail:

cherep.av.znu@

gmail.com

DOI:

10.24263/2304-

974X-2017-7-2-15

\section{Abstract}

Introduction. It was analyzed the modern approaches to the functioning of business incubators in Ukraine with the purpose of ensuring the initiation of effective structural changes in the national economy.

Materials and methods. The experience of creating and operating business incubators in the United States, Italy, Britain, Portugal, Brazil, China has become a material for research.

Results and discussion. Business incubators play an important role in the development of national economies. The creation of business incubators will provide conditions for the development of entrepreneurship in the agri-food sector, the creation of new jobs, the effective use of innovative capacity and resources.

The largest number of start-up projects is in the following areas: service $-17 \%$, trade $-13 \%$, industry $-9 \%$, IT $-8 \%$, hotel and restaurant business $-7 \%$, transport and agriculture $-6 \%$.

Implementation of the main functions of business incubators, namely: business expertise for new enterprises and financing contribute both to the economic development of regions and increasing their investment attractiveness, and to the development of entrepreneurship, ensures the implementation of innovative ideas, creating additional jobs, and improving the welfare of the population.

In Ukraine the prospects of business incubators are determined by the following factors: increasing demand of business structures for new training technologies, consulting and information support; increasing demand of potential investors that not only should firms prove their steady material and financial position but also show an ability to dispose of investments provided to them; credit policy of banks forbidding companies to take up loans to purchase fixed assets, especially buildings, office and other equipment which results in an increase of their costs and reduction of current assets; pre-final stage of market formation which increases competition and makes business spend more time on sales of goods (services), diverting their attention from issues of functional management and strategic marketing; time needed for startups to develop and adapt to the market under terms of the current fiscal policy.

Conclusion. The study of the history of the creation of business incubators in the world made it possible to identify the main directions of innovative entrepreneurship and the prospects for its development in Ukraine. 


\section{Economics and Management -}

\section{Introduction}

Entrepreneurial activity represents a mechanism of society's socio-economic life, which forces companies to introduce new technologies and creates competition promoting application of innovative technical equipment that can accelerate the product development process resulting in improvement of efficiency of production and economy as a whole. Thus, it is safe to say that development of enterprises depends on the functioning of country as a whole. Therefore, the development of business incubators in Ukraine is a certain impetus for development of the entire country's economy.

The problems of business incubators functioning were researched in the works by the following scholars, namely: J. Bone, O. Allen, C. Haley. (2017), J. Bruneel, T. Ratinho, B. Clarysse, A. Groen (2012), L. M. Vasiliev (2010), R. Grimald, A. Grandi (2005), S. Mian, W. Lamine, A. Fayolle (2016), J. M. Shepard (2013), R. I. Zavadiak, Ya. F. Kopusiak 92014), T. V. Kysil (2013), A. B. Nemchenko, T. B. Nemchenko (2010), V. Yu. Frolova, H. I. Frolova (2010), L. T. Shevchuk, A. V. Kolodiichuk (2013), Wenqing Wu, Qing Han (2017). However, we consider it necessary to carry out generalization and systematization of the theoretical grounds of business incubators development, given the existing world and domestic experience. The development of entrepreneurship in agriculture and the food sector is important for the economies of different countries.

The agri-food sector plays a leading role in the economic development of Ukraine.

The creation of business incubators will provide conditions for the development of entrepreneurship in the food industry, the creation of new jobs, the effective use of innovative capacity and resources.

Aim of the research is deepening of the theoretical foundations for development of business incubators, revealing the peculiar features of business incubators functioning under modern conditions, identifying the measures for business incubators successful development, given the international and domestic experience.

\section{Materials and methods}

Business incubators, which are innovative structures, are examined in the article. Business incubators contribute to the development of innovative entrepreneurship and help in the implementation of start-ups. The main task of business incubators is to ensure effective conditions for the creation and development of start-ups. Innovative ideas are the basis of start-ups. Innovative ideas are one of the main factors of competition in the modern world. Innovations provide competitive advantages to start-ups. The effectiveness of introducing innovations provides start-ups with a stable market position.

The role of business incubators is to provide the necessary support when preparing and presenting the project to the investor. The business incubator avoids the typical mistakes by providing consulting services in the derivation of projects. It helps in finding investors. World experience of organization of business incubators and trends of development of business incubators in Ukraine have been studied to ensure the reliability of the results during the research.

The method of statistical analysis was used in the study of data from the State Statistics Service of Ukraine and business associations.

Theoretical and methodological approaches, which were highlighted in the works of scientists [1-6], were used in research. 
The study of the main characteristics and functions of business incubators from different countries of the world make it possible to forecast trends in the development of innovative entrepreneurship in Ukraine.

The results of the studies are obtained through the use of grouping methods, generalizations and comparisons. The graphical method is used to provide visibility of the obtained results.

\section{Results and discussion}

Business incubators are the object of research by scientists in many countries. Ukraine is passing the period of the formation of business incubators. Business incubators serve as a role for the development and support of small and medium-sized businesses in the economies of developed countries. There are many varieties of business incubators. They differ in size, forms of interaction with start-ups, venture capitalists.

Studying the experience of the formation of business incubators of other countries will allow to build an effective model of business incubators in Ukraine. The material for writing the article was the experience of business incubators in the USA, Italy, UK, Portugal, Brazil, China.

Business incubators are effective instruments for the development of new firms. The authors studied the mechanisms of cooperation between business incubators and venture capitalists and proposed three mechanisms for interaction between business incubators and venture capitalists: revenue sharing mechanism, cost sharing mechanism and knowledge sharing mechanism. Wenqing Wu, Qing Han (2017) consider the effect of the business nonprofit incubators and compare the three cooperation mechanisms in the profit incubators. The results indicate that the mechanism of revenue sharing leads to the highest incubator's revenue sharing proportion. Additionally, the incubator's revenue sharing proportion decreases even though its final profit increases when considering altruism. Therefore, the nonprofit incubator can be better for cooperating with the venture capitalist than the profit incubator [1].

Luisa Margarida Cagica Carvalho, Simone Vasconcelos Ribeiro Galina (2015) presented a comparative study on the specifics of business incubators to promote the development of new companies in Portugal and Brazil [2].

Rosa Grimald, Alessandro Grandi (2005) argue that the variety of incubating organizations is driven by the evolution of companies' requirements and needs. These needs requirements contribute to the differentiation of the range of services by incubators. The authors identify four types of incubators and a list of variables incubator characteristics that help to describe the incubation models. The authors obtained empirical data on two incubating models based on the studies of eight Italian incubators [3].

Johan Bruneel,Tiago Ratinho, Bart Clarysse, Aard Groen (2012) show the accelerator as a new generation incubation model. Accelerators have become an umbrella term for any program providing a service structure of mentorship, networking opportunities and access to funding [4].

Sarfraz Mian, Wadid Lamine, Alain Fayolle (2016) describe the features of incubators, accelerators and scientific parks as tools for business development. Science parks, incubators and accelerators are Technology Business Incubation mechanisms considered to be important policy tools for supporting innovation and technology-oriented entrepreneurial growth. Their popularity is premised on the belief that these mechanisms provide critical 
value-added inputs essential for the creation and development of innovative TechnologyBased Firms [5].

Jeffrey M Shepard, (2013) to discuss the historical evolution of business incubators from 1959 to the present. Three cohort periods were defined: 1959-1979, 1980-1999 and 2000-2012. The business characteristics of corporate mission, plans and strategies, leadership/management, staff competence and expertise, facilities and resources and technology were described for each cohort period [6].

Nowadays survival in fairly harsh conditions is crucial for companies without a sustainable economic and financial support. Power and invincibility are not determined by country's size but knowledge and ability to generate new ideas for sustainable economic mechanisms in competition. Small and medium-sized business is a locomotive of economic reforms as its stable and successful performance is a step into future. Today, application of modern approaches, the effectiveness of which is proved by global practice, is of significance to business and entrepreneurship development [7].

Ukraine is currently experiencing fundamental reform of its law system and its adaptation to new socio-economic conditions. Against this background, there arise many problems associated with entrepreneurial activities. In order to ease the situation, based on the amended and altered law of Ukraine "On state support of small business" No. 2063-III dated October 19, 2000, which provides for the legal framework for state support of small business irrespective of ownership form with a view to early recovery from the economic recession, the conditions for introduction and extension of market reforms in Ukraine are created.

Today, of urgency is the problem of effective use of business incubators as a form of institutional support for implementation and innovation, which will enhance entrepreneurship development. New economic conditions require active work and increased attention to forms of institutional support for innovative projects implementation.

The interest in business incubators is growing thus attracting the attention of the government, local authorities, academia, economists, etc. This interest is based on assisting small and medium-sized enterprises, and acts as a tool of ensuring economic growth, poverty reduction and elimination of territorial disparity through decentralization of development at the local or regional levels.

Business incubator is a structure that creates favourable conditions for functioning of start-ups by providing financial, informational and consulting services. Incubation provides necessary assistance to newly established businesses in acquiring necessary professionalism in the selected production area and rapid overcoming of problems arising in the process of their development and activities.

For the purposes of this study, we consider an incubator as being defined by the following characteristics: open-ended duration (exit usually based on the stage of the company, rather than a specific time frame); typically rent/fee-based; focus on physical space over services; admissions on ad-hoc basis (not cohort-based); provision of services including mentorship, entrepreneurial training; often provide technical facilities such as laboratory equipment; selective admission (but typically less so than accelerators) [8].

The main emphasis in the activities of business incubators is on encouragement of local and regional economies' development and creation of jobs.

In our opinion, business incubators are quite profitable and successful projects for improving the country's economic level. At present in Ukraine there are about 70 business incubators working in various fields. According to the data of 01.01.2014 provided by the State Committee of Ukraine on Entrepreneurship, in Ukraine there are 480 business centres, 79 business incubators, 50 technology parks, 538 leasing centres, 4148 non-banking 
financial institutions, 226 funds for support of entrepreneurship (among them 23 established with participation of the Ukrainian Fund for Entrepreneurship Support), 3034 investment and innovation funds and companies, 4238 information and consultation institutions $[9,10]$. For Ukraine these figures are not too high, neither they are low, however, that means we are approaching the current level of development in world countries. Our state has a great potential to enter the lists of the leaders in the production of individual product or service groups, but it is still very "immature" and therefore, we are faced with some problems, especially in the economic field.

The country's economy development depends on development of enterprises in its territory, as they determine the GDP rate, economy structure and living standards of the population. We constantly observe some progress: something is being modernized, new technologies and new management techniques are being introduced, everything is being done to improve the comfort of living, and, consequently, it results in gradual development of business incubators, a new for Ukraine form of assistance provided to small business.

The main objectives of business incubator are to provide small businesses with comprehensive services: legal and consulting services, information support, training for small enterprises, search for investors, lease of equipped office spaces, etc. The incubator is a specialized organization (or a large company division), whose main objective is creation of a local business environment favourable for small venture enterprises. The scale of incubator activities can be various: from a small incubator to incubator centres for small business development.

According to R. I. Zavadiak and Ya. F. Kopusiak [11], creation of first business incubators in Ukraine was stimulated by international financial assistance. Thus, at the end of the 1990-ies the Agency for International Development (USAID) funded the implementation of the Program on Business Incubation Development in Ukraine (BID). In the framework of this program the following business incubators were established: Kharkiv Technologies technological business incubator, business incubator of the Kherson Chamber of Industry and Commerce, business incubator of the Joint Trade Union of the Chernobyl Nuclear Power Station, etc.

The first business incubator in Ukraine was Happy Farm. It is located in the village of Shchaslyve, the Kyiv oblast. Per year Happy Farm holds 2 full cycles: from selection of teams to launch. Every start-up is supervised by experienced venture businessmen of the Happy Farm Supervisory Board.

The creation of business incubators in the agri-food sphere will help to resolve problems such as:

- research of niches in the agri-food sector to generate innovative products and services.

- ensuring interaction at different stages in the chain of production of agricultural products and food products.

- development of models for innovative management of subjects agricultural production and food production, processing, logistics and marketing.

- strengthening collaboration among academia and businesses to create innovation and share results.

- ensuring economic and environmental sustainability in agriculture and the food industry.

The development of entrepreneurship in agriculture and the food sector is important for the economies of different countries.

In 2016, the European Commission services (including Directorate General (DG) REGIO, DG JRC, DG AGRI and DG RTD) established the Thematic Smart specialisation Platform on Agri-food (S3P Agri-food) with the goal of accelerating the development 


\section{Economics and Management -}

of joint investment projects at the EU level in the smart specialisation areas linked to agriculture and food. With this initiative, the European Commission encourages the regions and member states to implement their Research and Innovation Strategies for Smart Specialisation (RIS3) strategies more efficiently. Regional stakeholders benefit from the new cooperation opportunities with partners from other regions [12].

Ukraine has great potential for development of the agrarian sector of national economy. The agricultural sector forms almost $19 \%$ of the Gross value added.

The business incubators ensure the development of entrepreneurship in the food industry, promote the creation of new jobs and the effective use of innovative capacities and resources.

Business incubator areas of activity are provided for by a business plan. It defines the amount and time of firms' participation in the incubator, the amount of financial and material resources needed for its work, principles and conditions of cooperation of the business incubator with launched start-ups.

There are many types of business incubators: non-profit, commercial, University research parks or science parks.

Non-profit business incubators are provided with funds by local authorities.

Commercial business incubators work on a commercial basis and demand partial refund of charges from their clients.

University research parks are branches of higher educational institutions established with support of enterprises, commercial banks, investment funds, which provide funding for development of a new generation of students. Such branches use educational services of professors, research and laboratory facilities of universities, their premises, technological equipment, library, etc.

Thus, in order to support innovative activities, the Kyiv Council initiated creation of an innovative business incubator, which includes the business incubator as a supervising body, coordination bodies to ensure cooperation with local authorities; independent centres to provide services to incubated firms and client firms. Innovative incubators work at Lviv, Dnipro and Kyiv technical universities. In 1996, in Ivano-Frankivsk the UkrainianCanadian Business Centre performing basic functions of a business incubator was created.

Let us consider the largest business incubators in Ukraine. GrowthUP was one of the first business incubators in Ukraine established in 2008 with the consulting company BayView Innovations. The cost of admission to a training session is $1200 \mathrm{UAH}$ for each project. GrowthUP receives $5 \%$ of the project authorized capital. The company intends to invest $\$ 25000-50000$ in best launched start-ups.

Polyteco Youth Business Incubator was established on the basis of the Kyiv Polytechnic Institute (KPI). It closely cooperates with Ukraine's first science park Kyivska Polytechnika, whose activities are aimed at commercialization of the Institute and start-ups' developments. Kyivska Polytechnika receives from 5\% to $20 \%$ of the start-up authorized capital. The incubator does not provide start-ups with start-up capital.

EastLabs was founded in January 2012. The project is financed by Viktor Pinchuk, and receives $15 \%$ of each start-up authorized capital. The incubator offers a training program, three jobs for each start-up and investment in the amount of 20 thousand US dollars for development of the business.

The first incubator of ideas from the USA in our country, Founder Institute, with headquarters located in the Silicon Valley offers the curriculum, which actually prepares start-ups for incubators of later stages, such as EastLabs or Happy Farm. Founder Institute acquires $3.5 \%$ of the start-up shares at a market price. The first investment in the company ranges from $\$ 50000$. 
Faster Capital from the UAE offers start-ups funding in exchange for a share in the project. As the incubator, Faster Capital provides assistance in assessing ideas, preparing feasibility study, market analysis, product development, sales and marketing as well as financial services until a start-up reaches the break-even point [13].

In 2016 the first Ukrainian Business InCUBubator for immature entrepreneurs initiated by Pryvatbank started its work. For months, the incubator collected more than 880 applications from participants who aim to start their own business or to expand the existing one. The projects were submitted by representatives of all oblasts (Figure 1) [14].

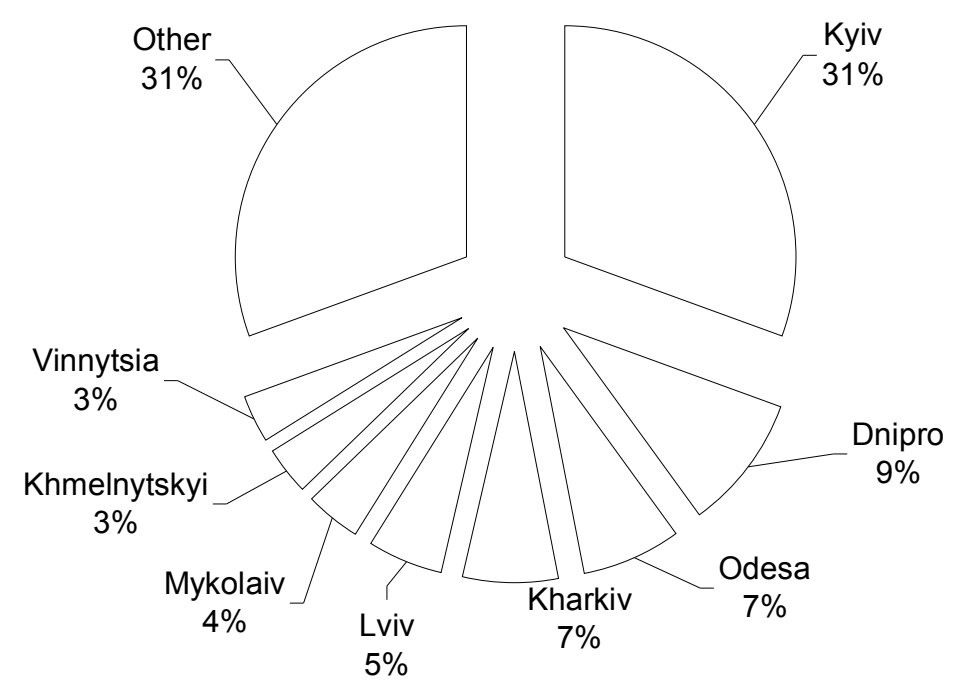

Figure 1. Number of projects registered with the Business Incubator by regions

According to Figure 1 the greatest number of start-up projects was submitted by Kyiv, Dnipro, Odesa and Kharkiv regions. The sectors, where entrepreneurs are to start their projects, are presented in Fig. 2.

Entrepreneurs associate most prospects for business with service sector. $17 \%$ of entrepreneurs would like to start their business in this sector. The second place is taken by trade prospects. $13 \%$ of applicants want to develop their business in this sector. Production, IT development and catering are third on the list of the most promising areas for Ukrainian small businesses [14].

The business incubator under consideration has generated a lot of interest from aspiring entrepreneurs. When choosing the finalists, the incubator management will consider possibilities of creating new jobs and implementing the project within six months.

Twenty finalists will have an opportunity to learn business and sales within a special Prometheus Program as well as to get support of experts and business coaches in organizing and planning their business, sales, accounting and legal issues. 


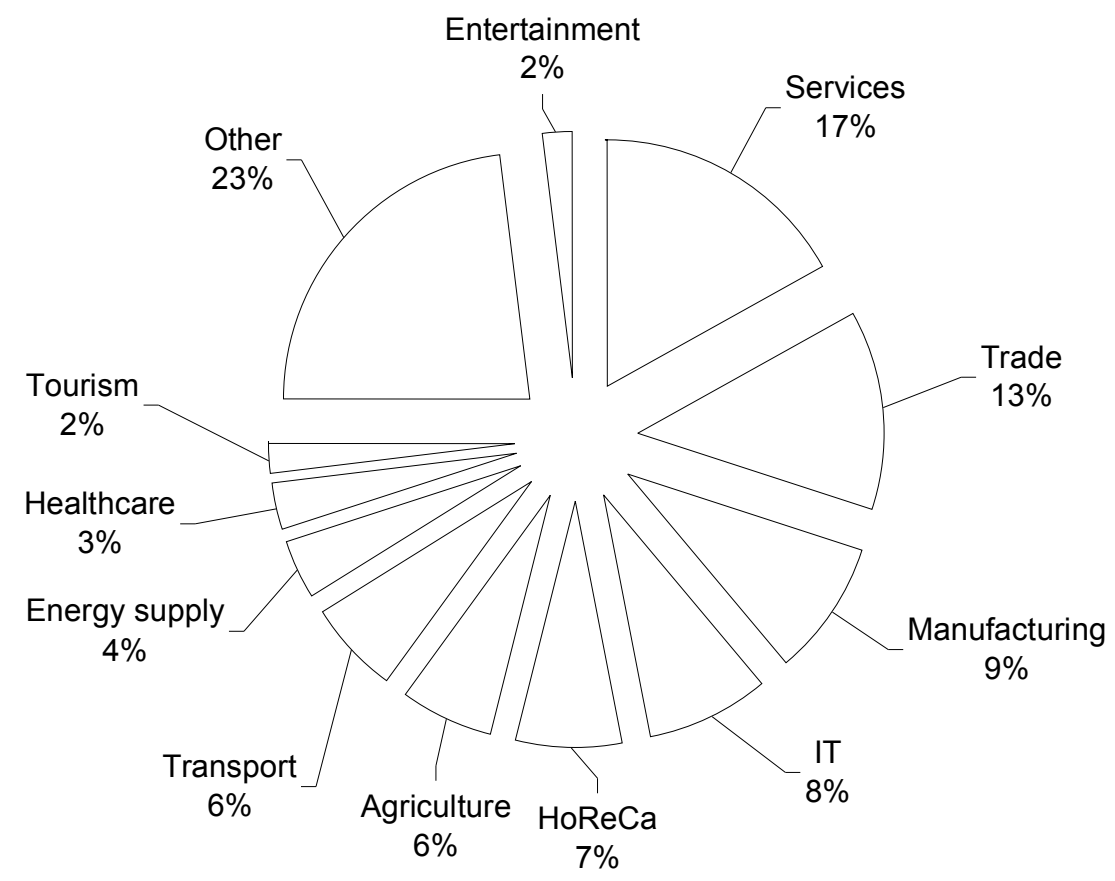

Figure 2. Sectors for project implementation registered with the Business Incubator (\%)

Successful participants of the business incubator will receive financial and organizational support from the PrivatBank.

The functions of incubators are constantly extended and modified; however, there are the major ones, which should be given as follows:

1. Business expertise for start-ups. Generally, in $90 \%$ of cases these services are provided to aspiring entrepreneurs to protect them against errors, which occur due to lack of confidence. It is therefore advisable that training and retraining of staff should be applied.

2. Financing customers. The more sources of funding are available, the better and more thorough consulting services are. Incubator experts' recommendations assist in obtaining loans or financing at early stages of company development.

3. Promoting economic development by increasing employment of population, business growth and formation of the infrastructure enterprises network. This explains the interest of regional administrations in development of incubators.

Business incubators take an important place in the innovation infrastructure. They are a tool of economic, social, structural and innovation policies.

The main advantage of business incubator for aspiring entrepreneurs, who experience financial difficulties, is that incubators provide them with protection and assistance on concessional terms, at below-market prices.

The important advantages of business incubator are a creative atmosphere, the image of a serious company, a list of required services, flexibility of management in the incubator. 


\section{Economics and Management -}

To facilitate the development of business incubators in Ukraine, the Ukrainian Association of Business Incubators and Innovation Centres was created. It contributes to implementation of national, regional, local and international programs aimed at development of entrepreneurship by establishing and supporting business incubators, technology parks, business support centres and other innovative structures as well as persons engaged in provision of services in the field of entrepreneurship [10].

Promoting entrepreneurship within ukrainian agri-food sector can be a strategy towards country economic development.

In Ukraine the prospects of agri-food business incubators are determined by the following factors:

- Increasing demand of business structures for new training technologies, consulting and information support;

- Increasing demand of potential investors that not only should firms prove their steady material and financial position but also show an ability to dispose of investments provided to them;

- Credit policy of banks forbidding companies to take up loans to purchase fixed assets, especially buildings, office and other equipment which results in an increase of their costs and reduction of current assets;

- Pre-final stage of market formation which increases competition and makes business spend more time on sales of goods (services), diverting their attention from issues of functional management and strategic marketing;

- $\quad$ Time needed for start-ups to develop and adapt to the market under terms of the current fiscal policy.

As far as world experience of business incubators use is concerned, within the 1990-ies of the XX century approximately $80 \%$ of new jobs were created by small business in Europe and the United States owing to activities of business incubators. The need for business incubation is also stipulated by the socio-economic nature of small business: 14$30 \%$ of newly established small enterprises only survive during the first three years of work, while in a business incubator this number increases significantly and accounts for 85$86 \%$. In order to encourage entrepreneurship, it is significant that business incubators ensure the provision of services at prices below the market level.

First business incubators appeared in the 1950-ies of the XX century in the United Kingdom [8]. However, the number of business incubators is the highest in the United States. As international experience shows, the most successful are the American, European and Asian models of business incubators. All the three models of business incubators are different. Most importantly, we should remember that incubator is a premise for implementation and generation of ideas of scientists, post-graduate students, University professors, engineers and innovators. Innovative "thoughts" and "ideas" are produced in symbiosis, which enables science to realize them within the industry in a short time and with immediate outcomes.

The American model is primary. The first modern business incubator, the Batavia Industrial Centre, was established in the USA in 1959 with the aim of increasing employment. One of the most successful business incubators in the United States includes [6]: business incubator to support FFVC high-tech companies in North Carolina, Affinity $\mathrm{Lab}$ in Washington to provide assistance to aspiring entrepreneurs, Alpha Lab in Pennsylvania to implement software and Internet projects.

In addition, the American model is characterized by a successful scheme of turning office centres of incubated enterprises into technology parks, in some cases - with the prospect of turning them into technology towns. 


\section{Economics and Management -}

What is the difference between the American model of business incubators creation and the European one? The European model mostly aims to organize large corporations. A lot of time is spent on research and development, thus showing that even a small company could make a breakthrough and surpass large enterprises, despite their large scale and great amount of funds allocated for research and development.

Thus, the Swedish experience demonstrates that business incubator is an effective tool for development of business environment of industrial enterprises, premise for generation and implementation of innovative ideas on the basis of large companies [15].

Another feature of the Finnish and Swedish models of business incubation is government encouragement of commercialization of innovative scientific research of University and research laboratory scholars with reservation of their intellectual property rights.

By their internal content European incubators are more specialized, they do not scatter forces and follow a high-tech direction in their work, support the unemployed. The American style is more "aggressive", egocentric and focused on direct promotion of the company.

In Italy business incubators serve as job centres, environment for innovation and support for small business, sources of innovative technological developments and centres for surplus labour force engagement for large corporations. It is also worth noting that in Italy small innovative enterprises "grown" in business incubators provide activities of large industrial corporations in terms of innovation [3].

The largest Italian business incubator is BIC Lazio, whose major directions are as follows: development of the Liguria region, support for start-ups and extension of business projects, project management, and support for technology transfer and entrepreneurship with assistance of scientists from the University of Genoa [16].

The characteristic features of the German model of creation and functioning of business incubators is, firstly, a high quality of training entrepreneurs (only $5 \%$ of enterprises "grown" in business incubators go bankrupt); secondly, reorientation of business incubators from innovations to support for small and medium-sized businesses. The second feature is related to the fact that in Germany business incubators are primarily considered as a tool for fostering regional social and economic development.

The first German business incubator was created in 1983 on the basis of the Technical University in Berlin.

Unlike Asian business incubators, the American technology sector sells services: contact programming, business outsourcing and contact production. This is the model adhered to by India, China and other East Asian countries as well as Brazil and Mexico.

The main features of Chinese business incubators are as follows:

- their scale - business incubators are operators for a large number of businesses;

- extensive introduction of achievements of the American model of business incubation [15].

Venture companies are active participants of innovative activity. The activities of such enterprises are focused on research, innovation and financing of innovation projects, though, they carry high risks.

European venture capital is very different from the US by social and cultural characteristics: if the American mentality sees defeat as a challenge, which encourages you to move forward, the European businessman, who failed at least with one project, will be forever considered unprofessional. Accordingly, the development of innovative activity in Europe is different. Certainly, there is Cambridge University, which, like Stanford, gathered around dozens of high-tech companies, but this is due to the fact that it is a 
relatively liberal Britain. The governments of France and Germany affect the economy and the market greatly, consequently, innovations in these countries are in the responsibilities of the state machinery, in other words, universities united in a single network, receive funds for innovative projects, acquiring similarity to American business incubators [6].

In the 1990-ies Internet incubators appeared. The number of business incubators is increasing due to active government support and high yield of incubators. Over the last ten years their number has grown from a few dozens up to 575, united within the National Business Incubation Association (NBIA). According to the NBIA, $87 \%$ of the enterprises, which have grown from business incubators, continue to work on the market. Without incubators, the share of operating companies can reduce to $50 \%$ [15].

The training and education programmes can enhance critical perceptions such as desirability, feasibility and conviction among farmers and inhabitants of cities to become entrepreneur in agri-food sector [17] .

\section{Conclusions}

The world and domestic experience of creation and activity of business incubators has shown that in the developed world they have become an indispensable characteristic of the market infrastructure, effective implementation of promising innovative business ideas and, consequently, a powerful engine of socio-economic development. Business incubators are an effective tool for creating small businesses and jobs, promoting cooperation of industrial enterprises and educational institutions. Moreover, business incubators encourage commercialization of new technologies and improve the image of the area of their functioning.

However, in Ukraine business incubation has not developed extensively and efficiently primarily due to ineffective government policies of encouraging business incubation development and scarcity of financial resources, lack of understanding of the role of business incubators as sources of business environment creation by many market actors.

One may have an impression that in Ukraine there is no real need for services of business incubators. In fact, technology parks, business incubators, innovation centres and similar organizations only deal with issues of infrastructure operation and "arrangement" of various benefits provision. Business incubators do not provide the service they are created for in the whole world, - assistance in creation and development of competitive companies, market leaders. The format of business incubators existence in Ukraine contradicts completely the successful world practice, where the focus is on provision of consulting, administrative and other management services for start-up company development.

For the process of business incubation to be successful, we suggest the following measures be taken:

- establishing a system of state policy to support organization and operation of business incubators;

- developing end-to-end projects for the network of business incubators in the regions of Ukraine;

- reducing the level of corruption;

- reforming the bureaucracy;

- joining organizational and economic effort for execution of complicated orders;

- stabilizing the political and economic environment as a core element of business development. 


\section{Economics and Management -}

Business incubation creates a firm foundation for development of an integrated system of innovative entrepreneurship and allows building a model of the training process methodology of doing business successfully.

Everything is subjected to the principle of improvement, i.e., everything around us is constantly being improved and we hope that eventually our country's experience will be in demand, as sharing experience is an appropriate and productive way to improve potential.

\section{References}

1. Wu W., Han Q. (2017), Revenue and Knowledge Cooperation Mechanisms between Business Incubators and Venture Capitalists for Collaborative Start-Ups, Theoretical Economics Letters, 7(5), Available at: http://www.scirp.org/(S(i43dyn45teexjx455qlt3d2q))/journal/PaperInformation.aspx?PaperID=78121

2. Luisa Margarida Cagica Carvalho, Simone Vasconcelos Ribeiro Galina, (2015) The role of business incubators for start-ups development in Brazil and Portugal, World Journal of Entrepreneurship, Management and Sustainable Development, 11 (4), pp. 256-267, DOI: 10.1108/WJEMSD-05-2015-0023

3. Grimald R., Grandi A., (2005) Business incubators and new venture creation: an assessment of incubating models, Technovation, 25(2), Available at: February 2005, pp. 111-121, DOI: 10.1016/S0166-4972(03)00076-2

4. Bruneel J., Ratinho T., Clarysse B., Groen A. (2012), The Evolution of Business Incubators: Comparing demand and supply of business incubation services across different incubator generations, Technovation, 32(2), pp. 110-121, DOI: 10.1016/S0166-4972(03)00076-2

5. Mian S., Lamine W., Fayolle A. (2016) Technology Business Incubation: An overview of the state of knowledge Technovation, 50-51, pp. 1-12, https://www.researchgate.net/publication/296695723_Technology_Business_Incubatio n_An_overview_of the state_of knowledge

6. Jeffrey M Shepard (2013), Small business incubators in the USA: a historical review and preliminary research findings, Journal of Knowledge-based Innovation in China, 5(3), pp. 213-233, DOI:10.1108/JKIC-07-2013-0013

7. Kysil, T.V. (2013). Biznes-inkubator - pogliad u maibutnie, Ekonomichni problemy stalogo rozvytku - Economical Problems of Sustainable Development: Proceeding of the International Scientific and Practical Conference, 2, pp. 89-91.

8. Bone J., Allen O., Haley C. Business incubators and accelerators: the national picture. BEIS research paper number 7, Available at:

https://assets.publishing.service.gov.uk/government/uploads/system/uploads/attachment_data/file/ 608409/business-incubators-accelerators-uk-report.pdf

9. Analitychnyi zvit pro stan i perspektyvy rozvytku malogo i serednogo pidpriiemnytstva $\mathrm{v}$ Ukraini, Analytical report on the state and prospects of small and medium-sized business development in Ukraine, Available at: www.dkrp.gov.ua/info/3226.htm/.

10. Ukrainska Asotsiatsia biznes-inkubatoriv i innovatsiinych tsentriv, The Ukrainian Association of Business Incubators and Innovation Centers, Available at: http://www.novekolo.info

11. Zavadiak R.I., Kopusiak, Ya.F. (2014), Teoretychni osnovy funktsionuvannia ta vydy biznes-inkubatoriv v Ukraini, Naukovyi visnyk Uzhgorodskogo universitetu, 2, pp.7881 . 
12. Stancova, K.C., Cavicchi, A.(2017), Dynamics of Smart Specialisation Agri-food Trans-regional Cooperation, S3 Policy Brief Series, 21, Available at: http://s3platform.jrc.ec.europa.eu/documents/20182/221449/JRC107257_CiampiStanc ova_Cavicchi_EUPolicyBrief.pdf/886f31c4-fdf3-416b-a3e4-d5ee8a33dce6

13. INVenture. Golovna storinka. Analitika, Available at: https://inventure.com.ua/

14. PAT KB "Privatbank", Available at: https://privatbank.ua/

15. Shevchuk, L.T., Kolodiichuk, A.V. (2013), Svitovyi i vitchiznianyi dosvid stvorennia i funktsionuvannia biznes-inkubatoriv, Regionalna 1, pp.178-184

16. Bic Liguria: una realtaa supporto di aspiranti imprenditori e piccoli imprenditori, Available at: http://www.iolavoroliguria.it4

17. Yaseen, A. (2018), Precursory effects on entrepreneurial behaviour in the agri-food industry, Jounal of Entrepreneurship in Emerging Economies, 10(1), pp. 2-22, Available at: https://www.emeraldinsight.com/doi/abs/10.1108/JEEE-08-2016-0029 